\title{
PENENTUAN KEBUTUHAN PROTEKSI PETIR PADA GEDUNG BERTINGKAT KANTOR BPJS KETENAGAKERJAAN CABANG BLITAR
}

\author{
Bambang Satriya Purwita, Ahmad Solihudin, Robin Prasetyo \\ Fakultas Teknik, Universitas Islam Balitar Blitar \\ email : Robinrekhein@gmail.com
}

\begin{abstract}
Lightning is natural phenomenon that is the result of electrostatic events in the cloud for their difference in charge between the clouds or the difference in charge between the cloud and the earth and become involved in the discharge and generate an electric arc that we can see as lightning. To protect the building from the danger of lightning strikes the lightning rod should be installed so that the building and electrical devices that are in, it are protected from over voltage from lightning strikes them. The finial project will discuss the calculation and the elevation of the external lightning protection system that has existed in the building of the Office of Employment Branch BPJS Blitar and compare it with the existing theories regarding the calculation of the lightning rod. From the calculation and elevation by the author can be concluded that the lightning rod mounted on the Office of Employment Branch BPJS Blitar cannot protect the building properly.
\end{abstract}

Keywords : lightning, lightning protection system, BPJS Blitar

\section{PENDAHULUAN}

Indonesia merupakan daerah konvektif paling aktif, sehingga tiga persyaratan untuk terbentuknya awan petir mudah terpenuhi. Menurut Prof. Dr. Ir. Tarcicius Haryono, M.Sc, tiga persyaratan tersebut, yaitu: (1) udara lembab dalam lapisan tebal $3 \mathrm{~km}$; (2) adanya insulasi yang memanasi permukaan tanah dan udara di atasnya; (3) atmosfer yang tidak stabil secara konvektif atau ada gaya apung termal bernilai positif. Menurut Badan Meteorologi Klimatologi dan Geofisika tingkat hari guruh per tahun yang mencapai 100 ataupun lebih memiliki potensi petir yang tinggi. Pembangunan infrastuktur Gedung bertingkat yang tinggi banyak menimbulkan permasalahan terutama mengenai perlindungan keamanan bangunan, karena struktur bangunan tinggi sangat rawan mengalami gangguan baik secara mekanik maupun gangguan alam. Dalam suatu perusahaan sistem operasional pengiriman data elektronik sangatlah penting. Hal ini bertujuan untuk meningkatkan produktivitas suatu proses bisnis yang dilaksanakan oleh perusahaan tersebut. Produktivitas produksi harus didukung dengan kehandalan perangkat telekomunikasi pengiriman data maupun suara. Berdasarkan data dari Kantor BPJS Ketenagakerjaan Cabang Blitar sistem proteksi tersebut sudah terpasang dengan baik, namun dalam kurun waktu tahun 2010 s.d. 2015 masih terdapat 2 kali kerusakan akibat sambaran petir dan menimbulkan kerugian secara langsung maupun tidak langsung.

Rumusan masalah yang diajukan sehubungan dengan latar belakang penelitian adalah:

a. Bagaimana menentukan ruang proteksi dari penangkal petir?

b. Bagaimana menghitung jarak aman sistem penangkal petir eksternal dari bangunan?

c. Bagaimana menghitung untuk menentukan tegangan lebih akibat sambaran petir langsung pada gedung bertingkat Kantor BPJS Ketenagakerjaan Cabang Blitar?

Tujuan penelitian ini adalah mengetahui tentang penentuan kebutuhan Sistem Proteksi Petir secara umum, dan khususnya yang menjadi di dalam tulisan ini proteksi yang terpasang pada gedung bertingkat Kantor BPJS Ketenagakerjaan Cabang Blitar akibat sambaran petir langsung 
pada bangunan gedung bertingkat Kantor BPJS Ketenagakerjaan Cabang Blitar dengan memperhatikan existing sistem pentanahan yang ada.

Berdasarkan latar belakang yang telah dijabarkan diatas maka pembahasan penulisan skripsi ini dibatasi pada :

1. Penekanan tugas akhir ini ialah sebagai berikut :

a. Penentuan ruang proteksi dari penangkal petir. Metode dan parameter petir diperoleh berdasarkan level atau tingkat proteksi yang mengacu pada standar SNI 03-7015-2004 dan untuk perhitungan kebutuhan Sistem Penangkal Petir ( SPP ) bangunan mengacu pada Standar IEC (International Electrotechnical Commission) 1662, dalam hal ini tidak menjelaskan prinsip kerja penangkap petir.

b. Perhitungan jarak aman sistem penangkal petir eksternal dari bangunan dengan memperhatikan sistem pentanahan yang ada pada Gedung Bertingkat Kantor BPJS Ketenagakerjaan Cabang Blitar dan tidak membahas SPP internal.

c. Perhitungan untuk menentukan tegangan lebih akibat sambaran petir langsung pada gedung bertingkat Kantor BPJS Ketenagakerjaan Cabang Blitar.

2. Perlindungan petir yang digunakan adalah penangkap petir yang ada pada gedung Kantor BPJS Ketenagakerjaan Cabang Blitar.

\section{KAJIAN LITERATUR}

Hujan merupakan salah satu fenomena alam yang terdapat dalam siklus hidrologi dan sangat dipengaruhi iklim. Keberadaan hujan sangat penting dalam kehidupan, karena hujan dapat mencukupi kebutuhan air yang sangat dibutuhkan oleh semua makhluk hidup.

Table 2.2 Tingkatkan Hujan Berdasarkan Intensitasnya

\begin{tabular}{|c|c|}
\hline Tingkatan & Intensitas (mm/menit) \\
\hline Sangat lemah & $<0.02$ \\
\hline Lemah & $0.02-0.05$ \\
\hline Sedang & $0.05-0.25$ \\
\hline Desar & $0.25-1$ \\
\hline Sangat deras & $>1$ \\
\hline
\end{tabular}

Sumber : Mori et. Al ( 1997 )

\section{Sistem Proteksi Petir}

Proteksi petir merupakan suatu usaha untuk melindungi suatu objek dari bahaya yang diakibatkan petir, baik itu secara langsung maupun tak langsung. Proteksi petir terdapat dua jenis, eksternal dan internal.

\section{Standar PUIPP}

Besarnya kebutuhan suatu bangunan akan suatu instalasi penangkal petir ditentukan oleh besarnya kemungkinan kerugian serta bahaya yang ditimbulkan bila bangunan tersebut tersambar petir.

Besarnya kebutuhan tersebut dapat ditentukan secara empiris berdasarkan indeks-indeks yang menyatakan faktor-faktor tertentu seperti ditunjukkan pada table dibawah ini dan merupakan penjumlahan $(\mathrm{R})$ dari indeks-indeks tersebut.

Tabel 2.2 Indeks A: Bahaya Berdasarkan Jenis Bangunan

\begin{tabular}{l|l} 
Penggunaan dan Isi & Indeks A
\end{tabular}




\begin{tabular}{|l|c|}
\hline $\begin{array}{l}\text { Bangunan biasa yang tak perlu diamankan baik bangunan } \\
\text { maupun isinya }\end{array}$ & -10 \\
\hline $\begin{array}{l}\text { Bangunan dan isinya jarang digunakan, Misalnya: didanau, } \\
\text { ditengah sawah atau ladang, menara atau tiang dari metal }\end{array}$ & 0 \\
\hline $\begin{array}{l}\text { Bangunan yang berisi peralatan sehari-hari atau tempat } \\
\text { tinggal. Misalnya: rumah tinggal, industri kecil dan stasiun } \\
\text { kereta api }\end{array}$ & 1 \\
\hline $\begin{array}{l}\text { Bangunan atau isinya cukup penting. Misalnya: menara air, } \\
\text { barang-barang berharga dan kantor pemerintah }\end{array}$ & 2 \\
\hline $\begin{array}{l}\text { Bangunan yang banyak sekali orang. Misalnya: bioskop, } \\
\text { sarana ibadah, sekolah, dan monumen bersejarah yang } \\
\text { penting. }\end{array}$ & 3 \\
\hline Instalasi gas, minyak atau bensin dan rumah sakit. & 5 \\
\hline $\begin{array}{l}\text { Bangunan yang mudah meledak dan dapat menimbulkan } \\
\text { bahaya yang tidak terkendali bagi sekirarnya. Misalnya: } \\
\text { instalasi nuklir. }\end{array}$ & 15 \\
\hline
\end{tabular}

sumber : Direktorat Penyelidikan Masalah Bangunan. Peraturan Umum Instalasi Penangkal Petir (PUIPP) untuk Bangunan di Indonesia. Hal 17

Tabel 2.3 Indeks B: Bahaya berdasarkan Konstruksi Bangunan

\begin{tabular}{|l|c|}
\hline \multicolumn{1}{|c|}{ Konstruksi Bangunan } & Indeks B \\
\hline $\begin{array}{l}\text { Seluruh bangunan terbuat dari logam dan mudah } \\
\text { menyalurkan listrik }\end{array}$ & 0 \\
\hline $\begin{array}{l}\text { Bangunan dengan konstruksi beton bertulang atau rangkan } \\
\text { besi dengan atap logam }\end{array}$ & 2 \\
\hline $\begin{array}{l}\text { Bangunan dengan konstruksi beton bertulang atau rangkan } \\
\text { besi dengan atap bukan logam }\end{array}$ & 3 \\
\hline Bangunan kayu dengan atap bukan logam & 1 \\
\hline
\end{tabular}

sumber : Direktorat Penyelidikan Masalah Bangunan. Peraturan Umum Instalasi Penangkal Petir (PUIPP) untuk Bangunan di Indonesia. Hal 18

Tabel 2.4 Indeks C: Bahaya berdasarkan Tinggi Bangunan

\begin{tabular}{|c|c|}
\hline Tinggi bangunan sampai...(m) & Indeks C \\
\hline 6 & 0 \\
\hline 12 & 2 \\
\hline 17 & 3 \\
\hline 25 & 4 \\
\hline 35 & 5 \\
\hline 50 & 6 \\
\hline 70 & 7 \\
\hline 100 & 8 \\
\hline 140 & 9 \\
\hline 200 & 10 \\
\hline
\end{tabular}

sumber : Direktorat Penyelidikan Masalah Bangunan. Peraturan Umum Instalasi Penangkal Petir (PUIPP) untuk Bangunan di Indonesia. Hal 19 
Tabel 2.5 Indeks D: Bahaya berdasarkan Situasi Bangunan

\begin{tabular}{|l|c|}
\hline \multicolumn{1}{|c|}{ Situasi Bangunan } & Indeks D \\
\hline Ditanah datar pada semua ketinggian & 0 \\
\hline $\begin{array}{l}\text { Dikaki bukit sampai 3/4 tinggi bukit atau di pegunungan } \\
\text { sampai 1000 meter }\end{array}$ & 1 \\
\hline $\begin{array}{l}\text { Di puncak gunung atau pegunungan yang lebih dari 1000 } \\
\text { meter }\end{array}$ & 2 \\
\hline
\end{tabular}

sumber : Direktorat Penyelidikan Masalah Bangunan. Peraturan Umum Instalasi Penangkal Petir (PIUPP) untuk Bangunan di Indonesia. Hal 19

Tabel 2.5. Indeks E: Bahaya berdasarkan Hari Guruh

\begin{tabular}{|c|c|}
\hline Hari Guruh per tahun & Indeks E \\
\hline 2 & 0 \\
\hline 4 & 1 \\
\hline 8 & 2 \\
\hline 16 & 3 \\
\hline 32 & 4 \\
\hline 64 & 5 \\
\hline 128 & 6 \\
\hline 256 & 7 \\
\hline
\end{tabular}

sumber : Direktorat Penyelidikan Masalah Bangunan. Peraturan Umum Instalasi Penangkal Petir (PUIPP) untuk Bangunan di Indonesia. Hal 19

Dengan memperhatikan keadaan di tempat yang hendak di cari resikonya dan kemudian menjumlahkan indeks - indeks tersebut di peroleh suatu perkiraan bahaya yang di tanggung bangunan dan tingkat yang harus di terapkan. Di bawah ini adalah tabel Perkiraan bahaya Sambaran Petir Berdasarkan PUIPP.

\section{Berdasarkan PUIPP, perkiraan bahaya petir adalah sebagai berikut:}

Tabel 2.6 Perkiraan Bahaya Sambaran Petir

\begin{tabular}{|c|c|c|}
\hline R & Perkiraan Bahaya & Pengamanan \\
\hline Di bawah 11 & Diabaikan & Tidak perlu \\
\hline Sama dengan 11 & Kecil & Tidak perlu \\
\hline Sama dengan 12 & Sedang & Dianjurkan \\
\hline Sama dengan 13 & Agak besar & Dianjurkan \\
\hline Sama dengan 14 & Besar & Sangat Dianjurkan \\
\hline Lebih dari 14 & Sangat besar & Sangat Perlu \\
\hline
\end{tabular}

Sumber: Direktorat Penyelidikan Masalah Bangunan Peraturan Umum Instalasi Penangkal Petir (PIUPP) untuk Bangunan di Indonesia. Hal 19

Sehingga didapat perkiraan bahaya akibat sambaran petir $(\mathrm{R})$ adalah:

$$
\mathrm{R}=\mathrm{A}+\mathrm{B}+\mathrm{C}+\mathrm{D}+\mathrm{E} \text {. }
$$

Dimana:

A : Bahaya berdasarkan jenis bangunan

B : Bahaya berdasarkan konstruksi bangunan

C : Bahaya berdasarkan tinggi bangunan 
D : Bahaya berdasarkan situasi bangunan

E : Bahaya berdasarkan hari guruh yang terjadi

Apabila menurut data-data yang ada dimasukkan ke dalam persamaan di atas, maka selanjutnya dapat diambil kesimpulan mengenai perlu atau tidaknya system proteksi petir eksternal digunakan.

$\mathrm{R}>13$

Berdasarkan SNI, Jika nilai $\mathrm{R}>13$, maka bangunan tersebut dianjurkan menggunakan sistem proteksi petir (besar indeks dapat dilihat pada lampiran A). Jelas bahwa semakin besar nilai R, semakin besar pula bahaya serta kerusakan yang ditimbulkan oleh sambaran petir, berarti semakin besar pula kebutuhan bangunan tersebut akan adanya suatu sistem penangkal petir.

\section{Standar Nasional Indonesia}

Berdasarkan Standar Nasional Indonesia (SNI 03-7015-2004), pemilihan tingkat proteksi yang memadai untuk suatu system proteksi petir berdasarkan pada frekuensi sambaran petir langsung setempat $(\mathrm{Nd})$ yang diperkirakan ke struktur yang di proteksi dan frekuensi sambaran petir tahunan setempat $(\mathrm{Nc})$ yang diperbolehkan.

Tabel 2.7 Efisiensi Sistem Proteksi Petir

\begin{tabular}{|c|c|}
\hline Tingkat Proteksi & Efesiensi SPP \\
\hline I & 0,98 \\
\hline II & 0,95 \\
\hline III & 0,90 \\
\hline IV & 0,80 \\
\hline
\end{tabular}

Sumber: SNI 03-7015-2004 tentang Sistem proteksi petir terhadap bangunan gedung

Setelah diketahui tingkat proteksi berdasarkan tabel 2.6, maka dapat ditentukan sudut proteksi $\left(\alpha^{\mathrm{o}}\right)$ dari penempatan suatu terminasi udara, radius bola yang dipakai, maupun ukuran jala (konduktor horizontal) sesuai dengan tabel 2.7 dibawah ini:

Tabel 2.8 Daerah Proteksi dan Terminasi Udara Sesuai dengan Tingkat Proteksi

\begin{tabular}{|c|c|c|c|c|c|c|}
\hline $\begin{array}{c}\text { Tingkat } \\
\text { Proteksi }\end{array}$ & R (m) & $\begin{array}{c}\mathbf{2 0} \\
\boldsymbol{\alpha}^{\mathbf{0}}\end{array}$ & $\begin{array}{c}\mathbf{3 0} \\
\boldsymbol{\alpha}^{\mathbf{0}}\end{array}$ & $\begin{array}{c}\mathbf{4 5} \\
\boldsymbol{\alpha}^{\mathbf{0}}\end{array}$ & $\begin{array}{c}\mathbf{6 0} \\
\boldsymbol{\alpha}^{\mathbf{o}}\end{array}$ & $\begin{array}{c}\text { Lebar } \\
\text { Jala (m) }\end{array}$ \\
\hline I & 20 & 25 & $*$ & $*$ & $*$ & 5 \\
\hline II & 30 & 35 & 25 & $*$ & $*$ & 10 \\
\hline III & 45 & 45 & 35 & 25 & $*$ & 15 \\
\hline IV & 60 & 55 & 45 & 35 & 25 & 20 \\
\hline
\end{tabular}

Sumber: Standar Engineering Pertamina 1999, Hal. 42

\section{Tahanan pentanahan}

Tabel 2.12 Harga tahanan jenis tanah

\begin{tabular}{|l|c|}
\hline \multicolumn{1}{|c|}{ Jenis tanah } & $\begin{array}{c}\text { Resistansi Jenis } \\
(\mathbf{O h m} \mathbf{~ m})\end{array}$ \\
\hline Tanah, rawa & $10 \ldots 40$ \\
\hline
\end{tabular}




\begin{tabular}{|l|c|}
\hline Tanah liat \& tanah garapan & $40 \ldots 100$ \\
\hline Pasir basah & $50 \ldots 200$ \\
\hline Kerikil basah & $200 \ldots 3000$ \\
\hline Pasir/kerikil kering & $<10000$ \\
\hline Tanah berbatu & $2000 \ldots 3000$ \\
\hline Air laut \&air tawar & $10 \ldots 100$ \\
\hline
\end{tabular}

Sumber: PUIL 2000

\section{METODE PENELITIAN \\ Pendekatan Penelitian}

Ditinjau dari jenis datanya pendekatan penelitian yang digunakan dalam penelitian ini adalah pendekatan kualitatif. Adapun yang dimaksud dengan penelitian kualitatif yaitu penelitian yang bermaksud untuk memahami fenomena tentang apa yang dialami oleh subjek penelitian secara holistik, dan dengan cara deskripsi dalam bentuk kata-kata dan bahasa, pada suatu konteks khusus yang alamiah dan dengan memanfaatkan berbagai metode ilmiah (Moleong, 2007:6).

Adapun jenis pendekatan penelitian ini adalah deskriptif.Penelitian deskriptif yaitu penelitian yang berusaha untuk menuturkan pemecahan masalah yang ada sekarang berdasarkan data-data.

Jenis penelitian deskriptif kualitatif yang digunakan pada penelitian ini dimaksudkan untuk memperoleh informasi mengenai penentuan kebutuhan proteksi petir pada gedung bertingkat Kantor BPJSKetenagakerjaan cabang blitar.

\section{Tempat dan Waktu}

Kegiatan penelitian yang penyusun laksanakan selama 1 (satu) bulan ini adalah di Kantor BPJS Ketenagakerjaan Cabang Blitar, dengan alamat di Jalan Ir. Soekarno No. 71, Kota Blitar Jawa Timur. Dimulai pada tanggal 9 Agustus 2016 sampai dengan tanggal 9 September 2016.

\section{Metode Pengumpulan Data}

Metode pengumpulan data yang digunakan dalam penelitian ini meliputi:

\section{Metode Wawancara}

Wawancara adalah cara menghimpun bahan keterangan yang dilakukan dengan tanya jawab secara lisan secara sepihak berhadapan muka, dan dengan arah serta tujuan yang telah ditetapkan. Anas Sudijono (1996: 82) ada beberapa kelebihan pengumpulan data melalui wawancara, diantaranya pewawancara dapat melakukan kontak langsung dengan peserta yang akan dinilai, data diperoleh secara mendalam, yang diinterview bisa mengungkapkan isi hatinya secara lebih luas, pertanyaan yang tidak jelas bisa diulang dan diarahkan yang lebih bermakna.

Wawancara dilakukan secara mendalam dan tidak terstruktur dengan pedoman yang telah di buat.Teknik wawancara digunakan untuk mengungkapkan data tentang keberadaan sistem penangkal petir di Kantor BPJS Ketenagakerjaan Cabang Blitar.

\section{Metode Dokumentasi}

Suharsimi Arikunto (2002:206) metode dokumentasi adalah mencari data yang berupa catatan, transkrip, buku, surat kabar, majalah, prasasti, notulen rapat, legger, agenda dan sebagainya. Hadari Nawawi (2005:133) menyatakan bahwa studi dokumentasi adalah cara pengumpulan data melalui peninggalan tertulis terutama berupa arsip-arsip dan termasuk juga buku mengenai pendapat, dalil yang berhubungan dengan masalah penyelidikan. 


\section{Keadaan Lokasi}

Gedung Kantor BPJS Ketenagakerjaan Cabang Blitar terletak di wilayah Kelurahan Bendogerit, tepatnya J1. Ir. Soekarno No. 71 Kota Blitar sebelah selatan Makam Proklamator Ir. Soekarno.Gedung Kantor BPJS Ketenagakerjaan Cabang Blitar terdapat server yang digunakan untuk penyimpanan maupun pengiriman data.

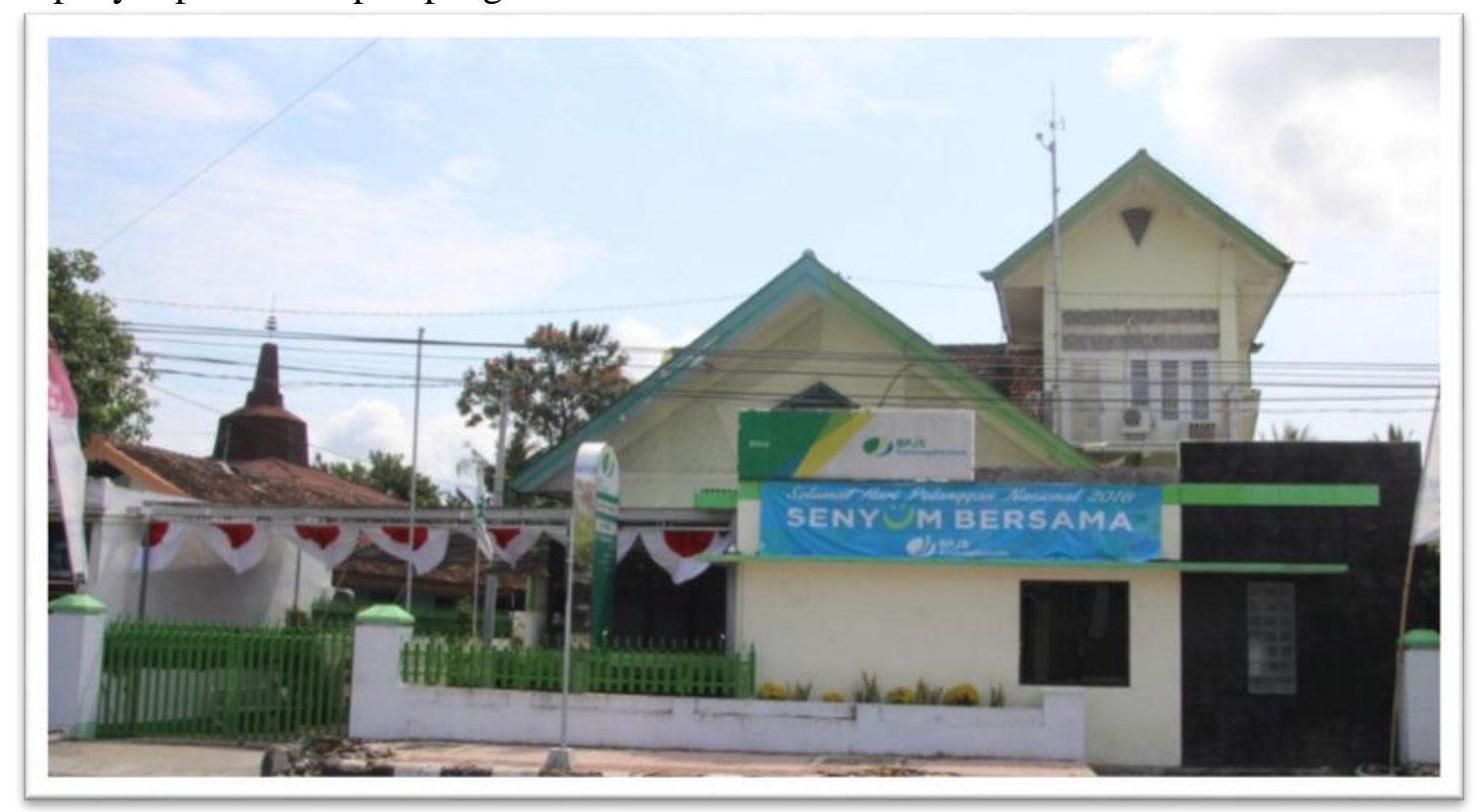

Gambar 3.1 Gedung Kantor BPJS Ketenagakerjaan Cabang Blitar

Kantor BPJS Ketenagakerjaan Cabang Blitar merupakan perusahaan yang bergerak dibidang jasa asuransi jiwa berskala nasional. Dengan ukuran area dan bangunan:
Luas lahan
$: 700 \mathrm{~m}^{2}$
Panjang
$: 35 \mathrm{~m}$
Lebar
$: 20 \mathrm{~m}$
Tinggi bangunan maksimum : $18 \mathrm{~m}$ 

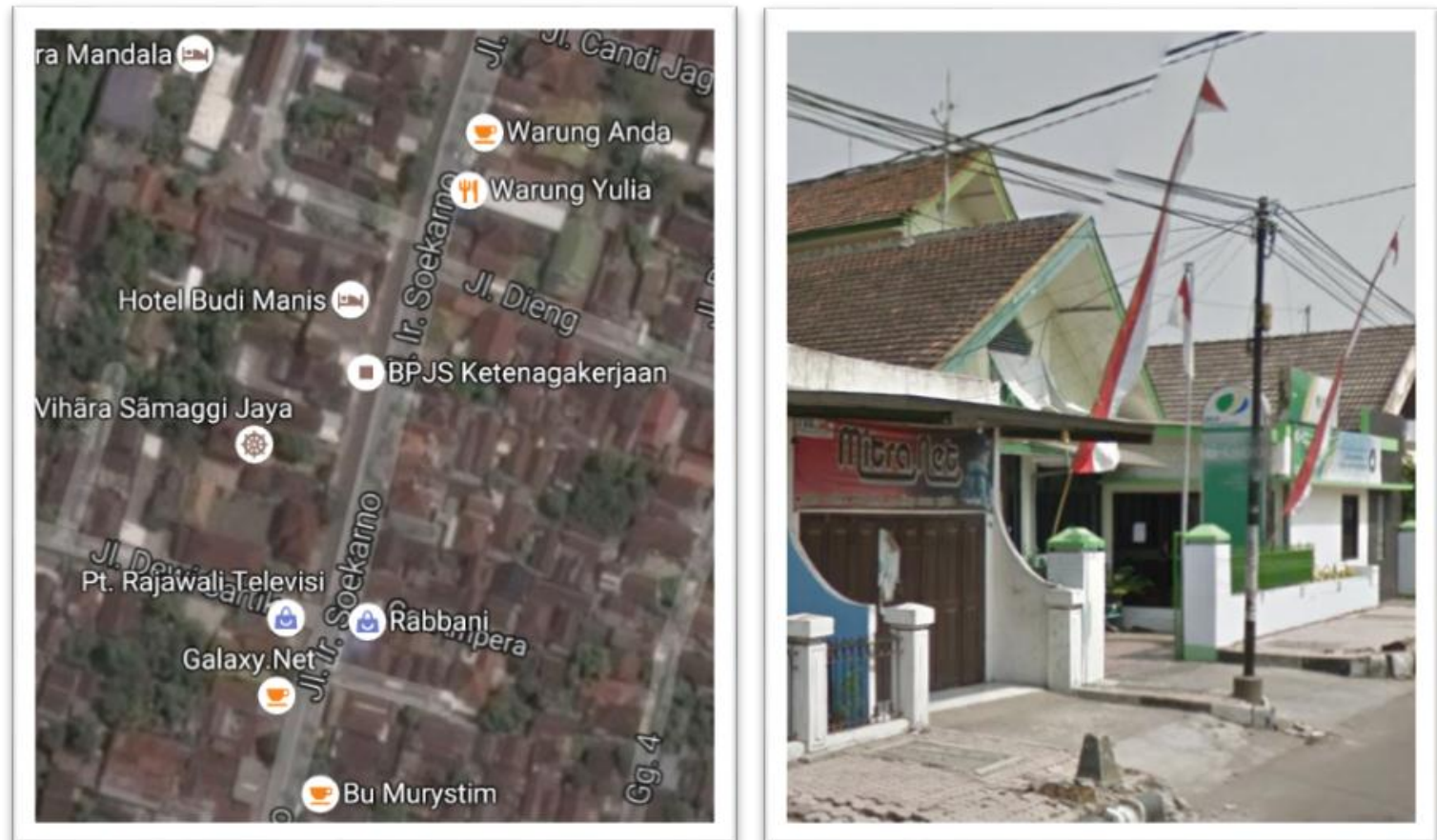

Sumber:

https://www.google.co.id/maps/place/8\%C2\%B005'17.2\%22S+112\%C2\%B010'26.5\%22

E/@-8.088113,112.1718513,749m/data=!3m2!1e3!4b1!4m5!3m4!1s0x0:0x0!8m2!3d-

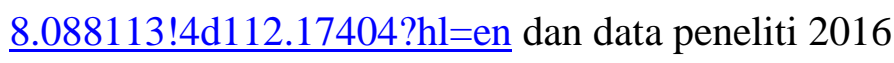

Gambar 3.1 Denah lokasi Kantor BPJS Ketenagakerjaan Cabang Blitar

Gedung Kantor BPJS Ketenagakerjaan terletak di tengah kota, tepatnya di Jl. Ir.

Soekarno. Terletak di sebelah utara dari Vihara Semanggi Jaya dan sebelah selatan dari

Hotel Budi Manis, searah dengan jalan menuju Makam Ir. Soekarno.

\section{Penangkal Petir Eksternal}

Penangkal petir yang digunakan di Kantor BPJS Ketenagakerjaan Cabang Blitar adalah penangkal petir konvensional lengkap dengan komponen-komponennya yang terpasang di gedung. Jumlah penangkal petir yang terpasang adalah sebanyak 2 buah.

Penangkal petir konvensional merupakan jalan atau penyalur bagi petir menuju ke permukaan bumi (earthing/grounding). Ada 3 bagian utama pada penangkal petir konvensional atau batang tombak atau split, kabel konduktor dan tempat pembumian. 


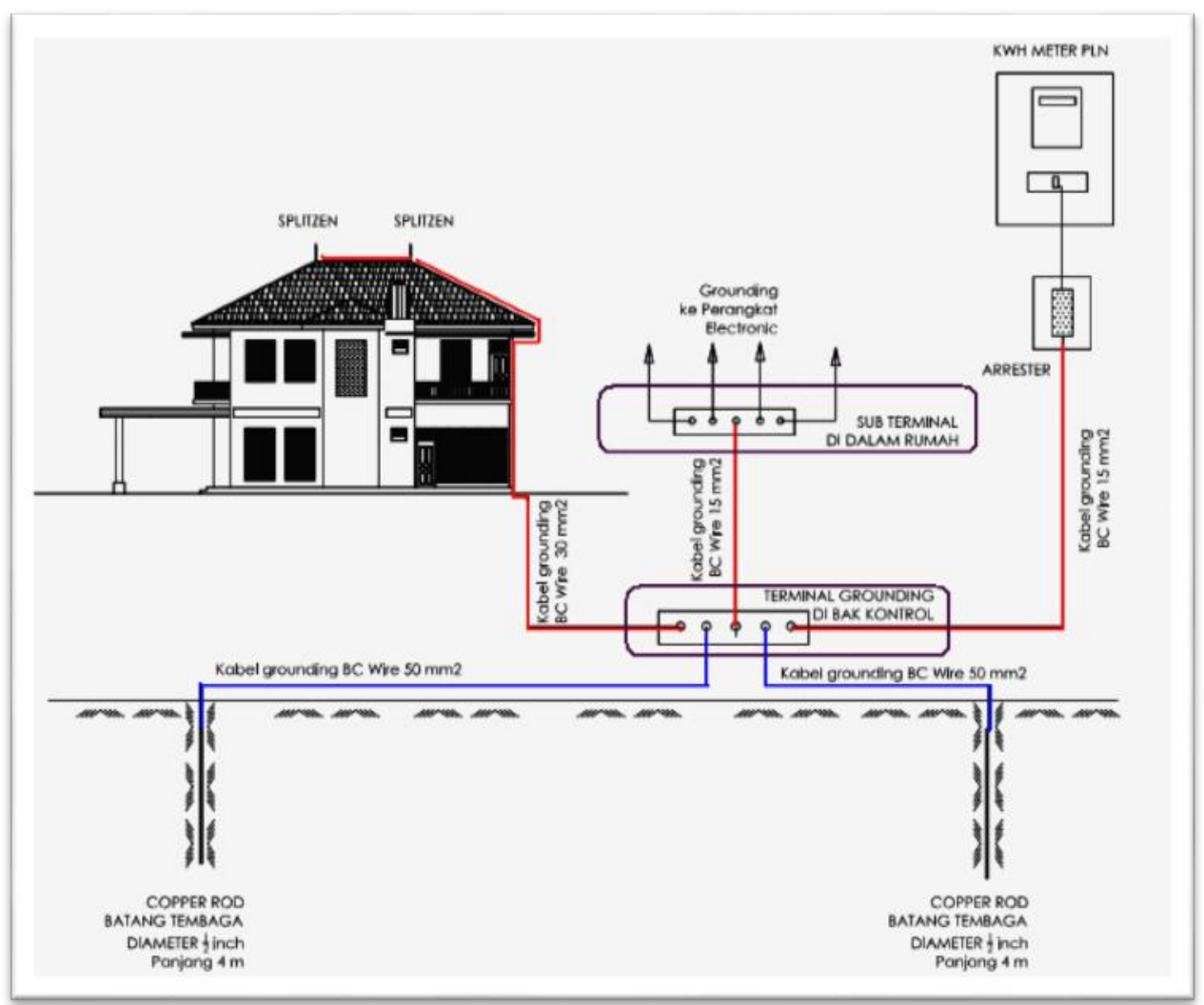

Sumber: http://www.plimbi.com/article/133182/mari-mengenal-alat-penangkal-petir-danbagaimana-k

\section{Gambar 3. 2 Sistem Kerja Penangkal Petir Jenis Konvensional}

Kantor BPJS Ketenagakerjaan Cabang Blitar menggunakan batang konvensional yaitu batang tembaga dengan ujung runcing. Batang konvensional dibuat runcing karena muatan listrik mempunyai sifat mudah berkumpul dan lepas pada ujung logam yang runcing itu. Sehingga terjadi kelancaran proses tarik menarik dengan muatan listrik yang aada di awan. Batang konvensional ini terletak di atas atap gedung Kantor BPJS Ketenagakerjaan Cabang Blitar.

Kabel konduktor / kabel BC yang digunakan gedung Kantor BPJS Ketenagakerjaan Cabang Blitar terbuat dari jalinan kawat tembaga. Diameter jalinan kabel konduktor sekitar $10 \mathrm{~mm}$. Kabel konduktor / kabel BC berfungsi meneruskan aliran muatan listrik dari batang bermuatan listrik ke tanah atau bumi.

Tempat pembumian (Grounding system) yang tertanam pada halaman gedung Kantor BPJS Ketenagakerjaan Cabang Blitar berfungsi mengalirkan semua muatan listrik dari kabel konduktor (kabel BC) ke batang pembumian (Ground Rod) yang tertanam di tanah. Batang pembumian pada Kantor BPJS Ketenagakerjaan Cabang Blitar terbuat dari tembaga murni, dengan diameter $10 \mathrm{~mm}$ dengan di masukkan pada pipa PVC dengan ukuran 8/4".

Gedung Kantor BPJS Ketenagakerjaan Cabang Blitar memiliki 2 lantai, dengan tinggi bangunan $18 \mathrm{~m}$. Gedung Kantor BPJS Ketenagakerjaan Cabang Blitar yang digolongkan memiliki jenis gedung biasa dan berkarakteristik terbuat dari beton dengan permukaan luar gedung beton atau paving. Struktur bangunan yang tinggi dan juga sever yang harus selalu online berpotensi besar mengalami kerusakan akibat sambaran petir, selain ketinggian banyak 
Bambang Satriya Purwita, Ahmad Solihudin, Robin Prasetyo. 2017. Penentuan Kebutuhan Proteksi Petir pada Gedung Bertingkat Kantor BPJS Ketenagakerjaan Cabang Blitar. Jurnal Qua Teknika, (2017), 7(2):27 42.

faktor lain diantaranya jenis permukaan atap, letak bangunan, ukuran bangunan dan bahan bangunan yang digunakan.

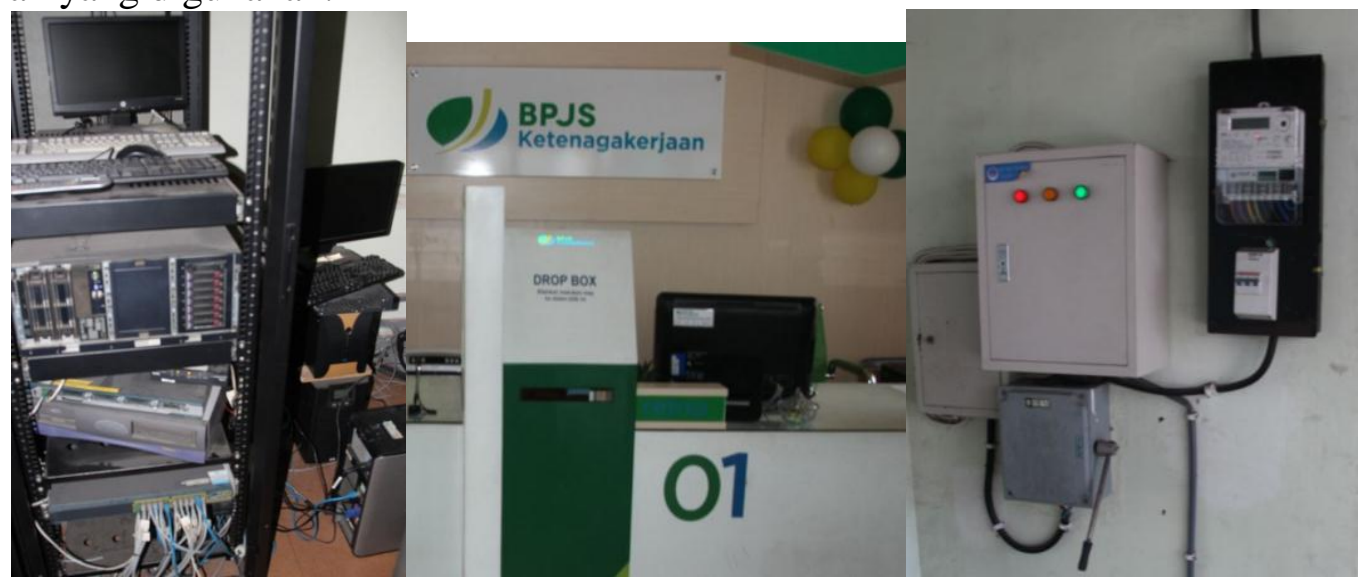

Sumber: Data Peneliti 2016

Gambar 3. 3 Peralatan yang rentan akibat sambaran surja petir pada Kantor BPJS Ketenagakerjaan Cabang Blitar

Mengingat letak Gedung Kantor BPJS Ketenagakerjaan Cabang Blitar terletak pada daerah yang rawan terhadap petir mencapai 121 kilat/tahun, sehingga untuk keamanan penyimpanan data peserta BPJS Ketenagakerjaan Cabang Blitar dan juga kenyamanan karyawan dimana para karyawan Kantor BPJS Ketenagakerjaan Cabang Blitar terhitung waktu hadirnya bekisar 1920 jam/tahun/orang untuk melakukan pekerjaannya salah satunya mengakses data peserta dalam keadaan apapun. Maka dari itu Kantor BPJS Ketenagakerjaan Cabang Blitar memberikan proteksi petir. Sistem proteksi petir yang digunakan Kantor BPJS Cabang Blitar adalah jenis konvensional dengan dua tombak.

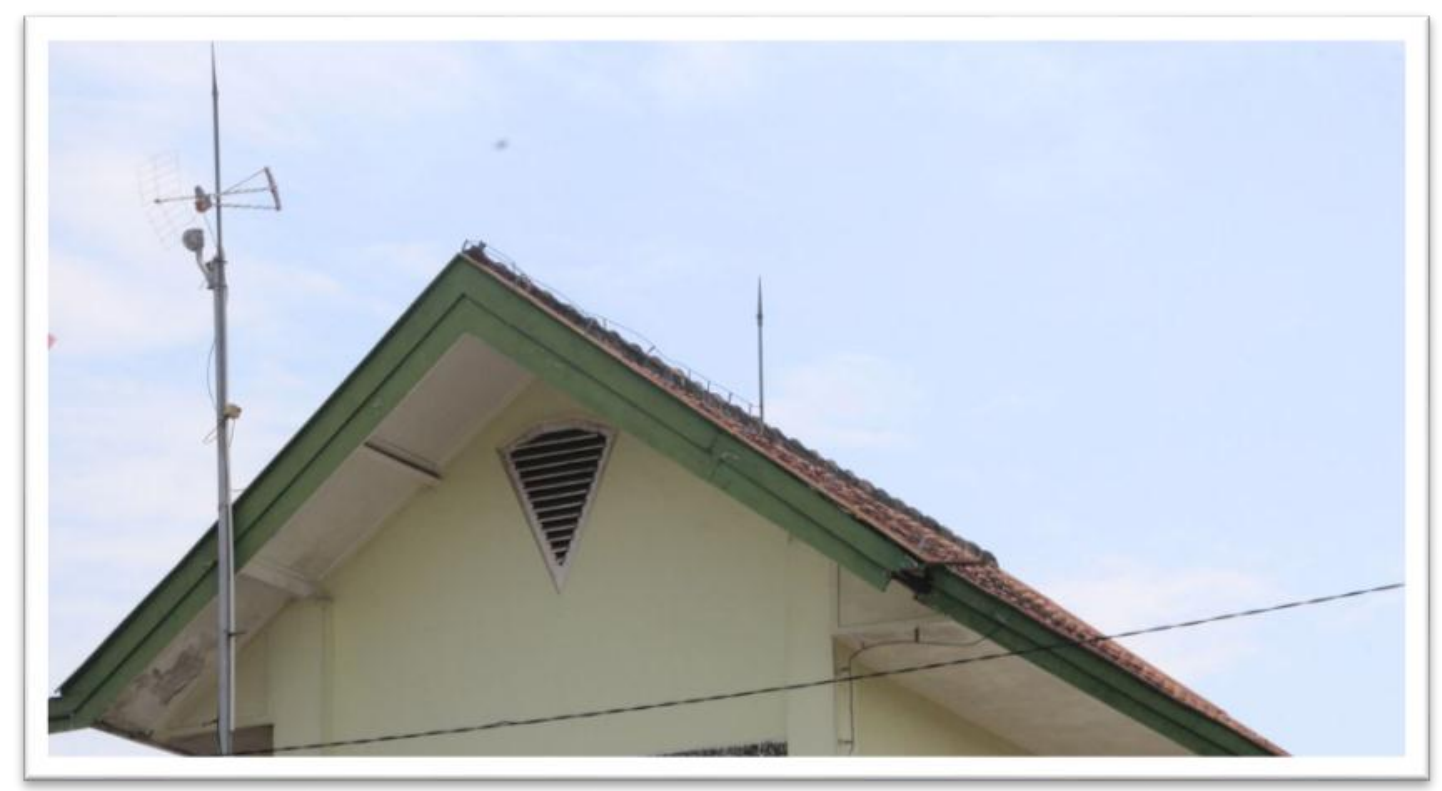

Sumber: Data Peneliti 2016

Gambar 3.4 penangkal petir eksternal Kantor BPJS Ketenagakerjaan Cabang Blitar 
Instalasi Penangkal Petir Eksternal pada Kantor BPJS Ketenagakerjaan Cabang Blitar

Instalasi penangkal petir yang terpasang pada Kantor BPJS Ketenagakerjaan Cabang Blitar mempunyai peralatan sebagai berikut:

Penangkal petir / split / tombak : : 2 buah

Penghantar Penyalur Utama : : 2 buah

Batang Pembumian

Penyalur petir ke-1 : 1 buah

Penyalur petir ke-2 : 1 buah

Dengan hasil pengujian besar tahanan pentanahan untuk setiap penyalur petir:

Penyalur petir pertama $\quad: 5 \mathrm{Ohm}$

Penyalur petir kedua $\quad: 5 \mathrm{Ohm}$

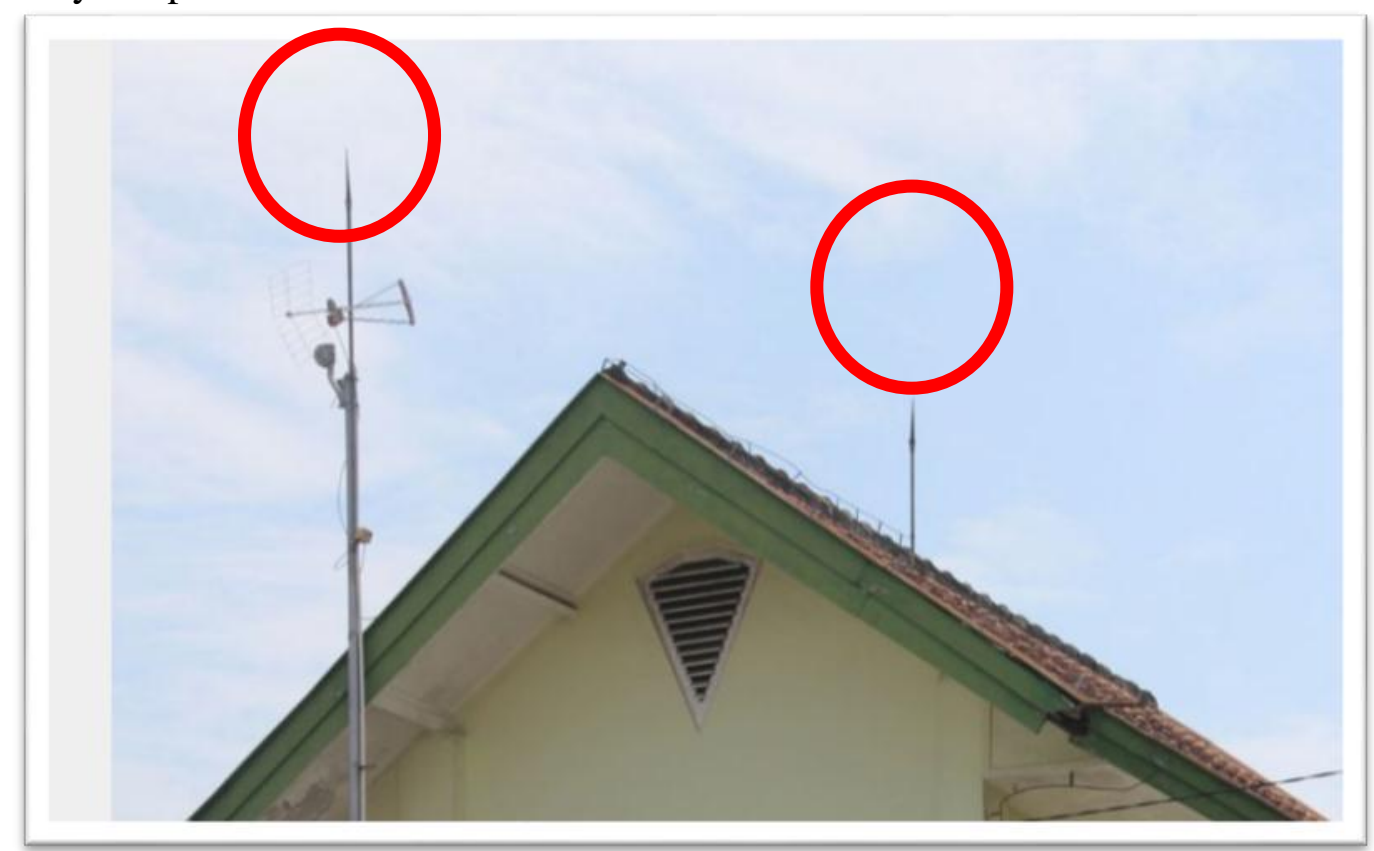

Sumber: Data Peneliti 2016

Gambar 3.5 penangkal petir pada kantor

\section{Lokasi Penempatan Penangkal Petir}

Dibawah ini merupakan lokasi penempatan penangkal petir Kantor BPJS Ketenagakerjaan Cabang Blitar, dimana tanda merah merupakan letak penangkap petir yang terpasang. Penangkal petir Kantor BPJS Ketenagakerjaan Cabang Blitar terletak tepat di gedung lantai dua, dimana gedung tersebut digunakan untuk ruangan server pada lantai 1. 


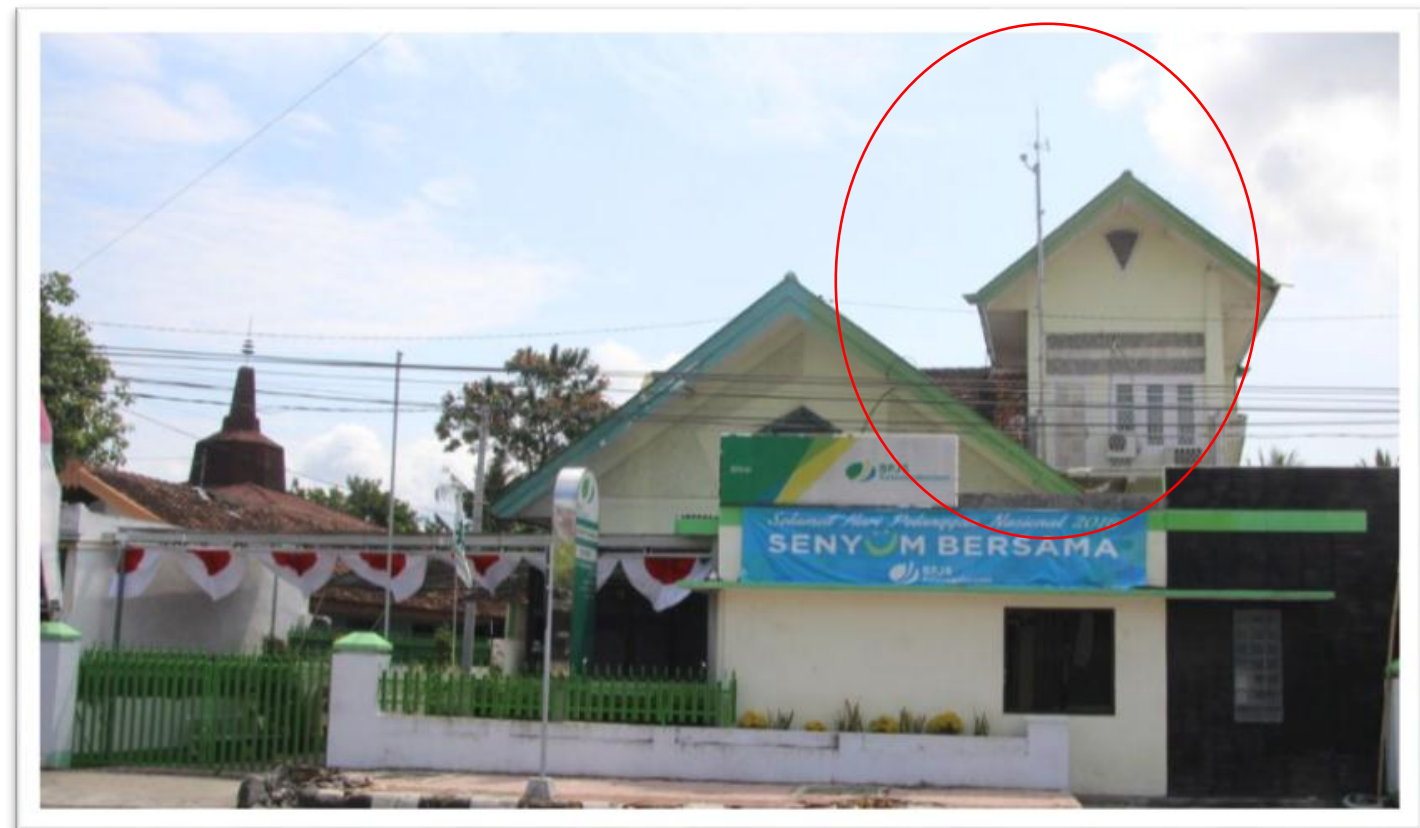

Sumber: Data Peneliti 2016

Gambar 3.6 Lokasi penempatan penangkal petir 1 dan 2

\section{Detail Peralatan Instalasi Penangkal Petir pada Kantor BPJS Ketenagakerjaan Cabang Blitar}

\section{Split / Batang Tombak}

Spesifikasi batang tombak (Split) yang terpasang pada Kantor BPJS Ketenagakerjaan Cabang Blitar :
Bahan
: Tembaga murni
Panjang
: $30 \mathrm{~cm}$
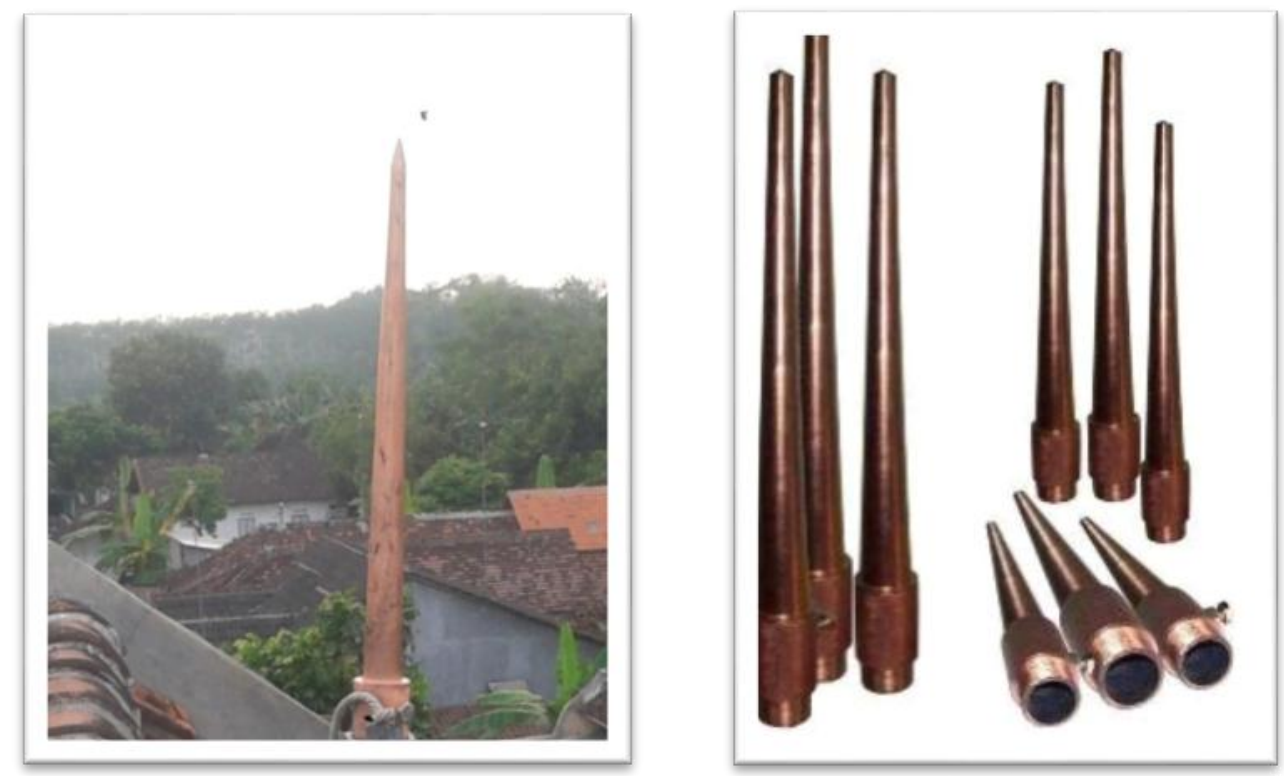
Sumber: Data Peneliti 2016 dan http://www.penangkalpetir.com/wp-

content/uploads/2014/08/splitzen-penangkal-petir.jpg

Gambar 3. 7 Splitzen tombak pada gedung Kantor BPJS Ketenagakerjaan Cabang Blitar

\section{Elektroda Pembumian}

Spesifikasi konduktor penangkal petir pada gedung Kantor BPJS Ketenagakerjaan Cabang Blitar:

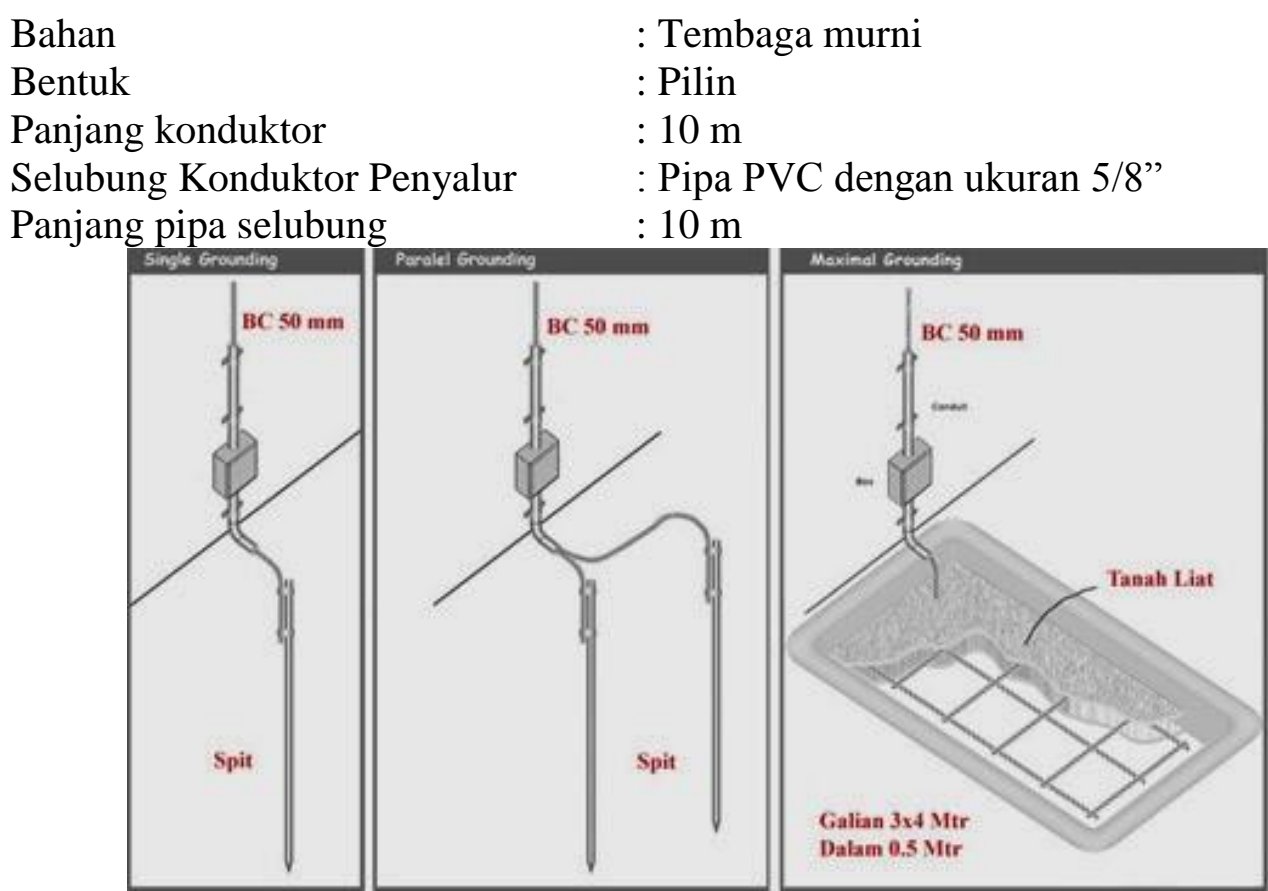

Gambar 3. 8 Sistem pembumian / Grounding System

Sumber: http://gudangpetir.com/wp-content/uploads/2015/04/max-grounding.gif 


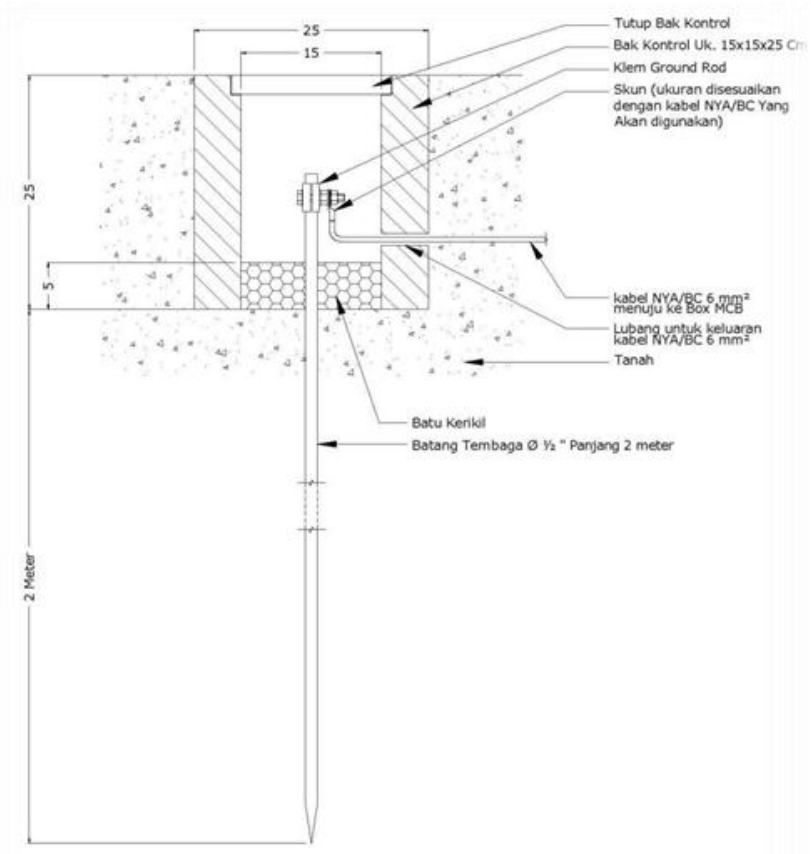

Sumber:

http://s1192.photobucket.com/user/jasa_instalasi/media/GroundingModel1.jpg.html Gambar 3.9 Sistem pentanahan

\section{HASIL DAN PEMBAHASAN}

Gedung Kantor BPJS Ketenagakerjaan Cabang Blitar yang terletak di J1. Ir. Soekarno No. 71 Kota Blitar ini berada di antara titik koordinat 112 ${ }^{\mathbf{0}} 14^{\prime}-\mathbf{1 1 2}^{\mathbf{0}} \mathbf{2 8}$ ' BT dan $\mathbf{8}^{0} 2^{\prime}-\mathbf{8}^{0} \mathbf{8}^{\prime}$ LS. Gedung ini dibangun diatas lahan seluas $700 \mathrm{~m}^{2}$. Data dimensi Gedung Kantor BPJS Ketenagakerjaan Cabang Blitar:

- Panjang bangunan

- Lebar bangunan

- Tinggi bangunan

$$
\begin{aligned}
& =35 \text { meter } \\
& =20 \text { meter } \\
& =18 \text { meter }
\end{aligned}
$$

Dari data-data yang di dapat pada tabel berdasarkan PUIPP yang ada pada bab lampiran tersebut ditentukan indeks-indeks untuk Gedung Kantor BPJS Ketenagakerjaan Cabang Blitar adalah

- $\quad$ Bangunan atau isinya cukup penting (Indeks A) $=2$

- Bangunan dengan konstruksi beton bertulang atau rangka besi dan atap bukan logam $($ Indeks B $)=2$

- $\quad$ Tinggi Bangunan \pm 18 meter (Indeks C) $=4$

- $\quad$ Di tanah datar pada semua kegiatan (Indeks E) $=0$

- $\quad$ Hari Guruh per tahun (Indeks E) $=6$

Maka di dapat nilai $\mathrm{R}$ adalah :

$\mathrm{R}=2+2+4+0+6=14$

Dengan nilai $\mathbf{R}=\mathbf{1 4}$, berdasarkan indek PUIPP menunjukkan bahwa gedung Kantor BPJS Ketenagakerjaan Cabang Blitar sangat memerlukan sistem proteksi petir.

Berdasarkan perhitungan di atas diperoleh nilai variabel-variabel yang paling penting adalah variabel jarak sambar petir dan radius daerah perlindungan karena kedua variabel ini dapat 
mempengaruhi kekuatan penangkal petir dalam dalam melindungi daerah perlindungannya baik gedung maupun peralatan yang berbeda didalam gedung.

\section{KESIMPULAN}

Berdasarkan penelitian yang telah dilakukan peneliti selama satu bulan, mulai dari 9 Agustus 2016 sampai dengan 9 September 2016. Kantor BPJS Ketenagakerjaan Cabang Blitar yang terletak di Jl. Ir. Soekarno No. 71 Kota Blitar ini berada di antara titik koordinat 112014' 112028' BT dan 802' - 808' LS.Gedung ini dibangun diatas lahan seluas $700 \mathrm{~m}^{2}$. Data dimensi Gedung Kantor BPJS Ketenagakerjaan Cabang Blitar dengan panjang bangunan 35meter, lebar bangunan 20 meter, dan tinggi bangunan 18 meter. Berdasarkan dari data-data yang di dapat pada tabel berdasarkan PUIPP yang ada pada bab lampiran tersebut ditentukan indeksindeks untuk Gedung Kantor BPJS Ketenagakerjaan Cabang Blitar adalah:

- $\quad$ Bangunan atau isinya cukup penting (Indeks A) $=2$

- Bangunan dengan konstruksi beton bertulang atau rangka besi dan atap bukan logam $($ Indeks B $)=2$

- $\quad$ Tinggi Bangunan \pm 18 meter (Indeks C) $=4$

- $\quad$ Di tanah datar pada semua kegiatan (Indeks E) $=0$

- $\quad$ Hari Guruh per tahun (Indeks E) $=6$

Maka di dapat nilai $R$ adalah $R=2+2+4+0+6=14$, dengan nilai $R=14$, berdasarkan indek PUIPP menunjukkan bahwa gedung Kantor BPJS Ketenagakerjaan Cabang Blitar sangat memerlukan sistem proteksi petir. Dimana lokasi Kantor BPJS Ketenagakerjaan Cabang Blitar memiliki kepadatan sambaran petir ke tanah sebesar $2 \mathrm{sambaran} / \mathrm{km}^{2} / \mathrm{tahun}$. Apabila kuat arus puncak petir melebihi 30,09 kA maka akan di alirkan ke penangkal petir, dengan muatan arus petir sebesar 4,75 Coulumb.

Sebaiknya gedung Kantor BPJS Ketenagakerjaan Cabang Blitar segera memperbaiki titik pentanahan yang tidak jelas atau mengganti sistem proteksi petir yang baru. Gedung Kantor BPJS Ketenagakerjaan Cabang Blitar sebaiknya menggunakan sistem proteksi petir jenis elektrostatis yang bekerja secara perlindungan radius dan beroperasi seperti penembak ion yang menembakkan dalam jumlah besar ion-ion ke angkasa pada saat petir menyambar dan akan secara otomatis membangkitkan lintasan petir yang lebih awal tersambar petir dibandingkan dengan titik yang mempunyai tinggi yang sama didekatnya sehingga mendapatkan radius maksimum daerah perlindungan.

\section{DAFTAR PUSTAKA}

Badan Meteoroli dan Geofisika, 2016, Prakiraan Curah Hujan Bulanan di Propinsi Jawa Timur 2016. Diambil dari : http://karangploso.jatim.bmkg.go.id

Badan Standarisasi Nasional, 2000, Persyaratan Umum Instalasi Listrik 2000 (PUIL 2000), Yayasan PUIL, Jakarta.

Badan Statistik Kota Blitar, 2015, Statistik Daerah Kota Blitar 2015. Diambil dari : https://blitarkota.bps.go.id/website/pdf_publikasi/Statistik-Daerah-Kota-Blitar-2015.pdf

Direktorat Penyelidikan Masalah Bangunan, 1983, Direktorat Penyelidikan Masalah Bangunan Peraturan Umum Instalasi Penyalur Petir (PUIPP) untuk Bangunan di Indonesia, Jakarta 2015, Menghitung Frekuensi Sambaran Petir di Indonesia. Diambil dari : http://www.pusatpenangkalpetir.com/2015/05/menghitung-frekuensi-sambaran-petirdi.html

Suzuki, T. April 1981. Study on Experimental Simulation on Lightning Strokes. IEE Trans. On Power Apparatur and Systems, Vol. PAS-100, No. 4. 
Jurnal Qua Teknika, Vol. 7 No. 2 September 2017

ISSN 2088 2424(cetak); 2527 3892(elektronik)

UNISBA Blitar, Http://qua.unisbablitar.ejournal.web.id

Bambang Satriya Purwita, Ahmad Solihudin, Robin Prasetyo. 2017. Penentuan Kebutuhan Proteksi Petir pada

Gedung Bertingkat Kantor BPJS Ketenagakerjaan Cabang Blitar. Jurnal Qua Teknika, (2017), 7(2):27 42.

Badan Standarisasi Nasional, 2004, Sistem Proteksi Petir Pada Bangunan Gedung (SNI 037015), Jakarta

Zoro, R., Sirait, K.T. 22-26 September 1996. Application of Lightning Peak Current Measurement System at Mountain Tangkuban Perahu, Proceedings Electropic'96, Jakarta, 